\title{
OBSERVER ERROR IN RECORDING ARTERIAL BLOOD PRESSURE
}

\author{
BY \\ W. F. ANDERSON AND N. R. COWAN \\ From the Consultative Health Centre for Older People, Rutherglen, Lanarkshire
}

Received September 12, 1960

The recording of blood pressure with a mercury manometer is subject to variation from two main sources, the individual observer error and change due to time sequence when repeated observations are recorded in a particular subject. The object of this paper is to study the observer error as between two observers in the estimation of blood pressure.

This analysis is based on data derived from the records of 510 men and women aged 60 to 89 years who were examined consecutively at the Rutherglen Consultative Health Centre for older people (Anderson and Cowan, 1955).

The blood pressures were estimated to the nearest even number using a mercury manometer with standard cuff with the subjects resting on an examination couch. The two readings noted were systolic blood pressure as the highest level at which successive sounds were heard, and diastolic blood pressure as the point where the loud clear sounds change abruptly to the dull and muffled sounds (Standardization of Methods of Measuring the Arterial Blood Pressure, 1939).

In each instance the blood pressure was recorded by two observers $A$ and $C$. One of the observers recorded the blood pressure approximately one minute after the other with the manometer cuff remaining in situ but completely deflated between readings; with each consecutive subject the observers took it in turn to be first. This procedure resulted in the 510 subjects forming a subgroup of 255 where $A$ read first and $C$ second, and a comparable group of 255 where $C$ read first and $A$ second. In the subsequent script these two groups will be identified as A1C2 and C1A2 respectively.

The difference between the first and second readings was stated to be positive or negative depending on whether the second reading was greater or less than the first, for example, if the first blood pressure recording (A1 or $\mathrm{Cl}$ ) is $170 \mathrm{~mm}$. and the second reading (A2 or $\mathrm{C} 2)$ is $180 \mathrm{~mm}$. the observer difference is $+10 \mathrm{~mm}$.

\section{RESULTS}

Table I shows the means with their standard errors and the standard deviations of the frequency distributions of the observer differences A1C2, C1A2, and both combined. Comparing the findings of systolic and diastolic blood pressure, these averages, which are all negative in sign, are all of

TABLE I

Means and Standard Deviations of the Observer Differences for Systolic and Diastolic Blood Pressure

\begin{tabular}{|c|c|c|c|c|c|c|c|}
\hline Blood pressure & & & & & Group & Mean \pm S.E. & Standard deviation \\
\hline Systolic mm. Hg & . & . & . & . & $\begin{array}{c}\mathrm{A} 1 \mathrm{C} 2 \\
\mathrm{C} 1 \mathrm{~A} 2 \\
\mathrm{~A} 1 \mathrm{C} 2+\mathrm{C} 1 \mathrm{~A} 2\end{array}$ & $\begin{array}{l}-1 \cdot 7 \pm 0.51 \\
-4 \cdot 3 \pm 0.63 \\
-3 \cdot 0 \pm 0.41\end{array}$ & $\begin{array}{r}8 \cdot 2 \\
10 \cdot 1 \\
9 \cdot 3\end{array}$ \\
\hline Diastolic $\mathrm{mm} . \mathrm{Hg}$ & $\cdots$ & $\ldots$ & . & $\cdots$ & $\begin{array}{c}\mathrm{A} 1 \mathrm{C} 2 \\
\mathrm{C} 1 \mathrm{~A} 2 \\
\mathrm{~A} 1 \mathrm{C} 2+\mathrm{C} 1 \mathrm{~A} 2\end{array}$ & $\begin{array}{l}-0.2 \pm 0.31 \\
-1.0 \pm 0.37 \\
-0.5 \pm 0.24\end{array}$ & $\begin{array}{l}4 \cdot 9 \\
5 \cdot 9 \\
5 \cdot 3\end{array}$ \\
\hline
\end{tabular}


greater magnitude for systolic blood pressure. The absolute variability of the observer differences (measured by the standard deviations) is smaller for diastolic blood pressure.

The summation of the observer difference means (A1C2 and C1A2) eliminates the observer error effect as between observers $\mathrm{A}$ and $\mathrm{C}$ and the extent to which the means of the combined distributions deviate from zero are indices of the influence of the time sequence on the observer difference in recording blood pressure. These means for the combined distributions of systolic and diastolic readings are $-3.0 \mathrm{~mm}$. and $-0.5 \mathrm{~mm}$. respectively.

The averages of the observer differences C1A2 for systolic and diastolic blood pressures are all of greater negative value than the corresponding averages for the observer differences A1C2 (Table I).

The subtraction of the average of the observer differences $\mathrm{A} 1 \mathrm{C} 2$ from those of $\mathrm{C1A} 2$, which is an index of the observer error effect as between observers $A$ and $C$ with the time sequence influence removed, is significant at three times the standard error of the difference between the comparable means $(2.6 \mathrm{~mm} . \pm 0 \cdot 81)$ for systolic, but is not significant for diastolic blood pressure $(0.8 \mathrm{~mm} . \pm 0 \cdot 48)$.

A study of the systolic observer difference distributions in Table II shows that when the observer

TABLE II

Frequency Distributions of Observer Differences in Systolic and Diastolic Blood Pressure

\begin{tabular}{|c|c|c|c|c|c|c|}
\hline \multirow{2}{*}{$\begin{array}{l}\text { Ot server } \\
\text { difference } \\
\mathrm{mm} . \mathrm{Hg}\end{array}$} & \multicolumn{3}{|c|}{ Systolic } & \multicolumn{3}{|c|}{ Diastolic } \\
\hline & $\mathrm{A} 1 \mathrm{C} 2$ & $\mathrm{C} 1 \mathrm{~A} 2$ & $\mathrm{~A} 1 \mathrm{C} 2+\mathrm{C} 1 \mathrm{~A} 2$ & $\mathrm{~A} 1 \mathrm{C} 2$ & $\mathrm{C} 1 \mathrm{~A} 2$ & $\mathrm{~A} 1 \mathrm{C} 2+\mathrm{C} 1 \mathrm{~A} 2$ \\
\hline $\begin{array}{l}+36 \\
+28 \\
+24 \\
+22\end{array}$ & $\begin{array}{l}-1 \\
1 \\
-\end{array}$ & $\frac{1}{1}$ & $\begin{array}{l}1 \\
1 \\
1 \\
1\end{array}$ & & & \\
\hline $\begin{array}{l}+20 \\
+18 \\
+16 \\
+14\end{array}$ & $\begin{array}{c}-1 \\
3 \\
6\end{array}$ & $\frac{1}{2}$ & $\begin{array}{l}1 \\
1 \\
5 \\
8\end{array}$ & $\begin{array}{l}1 \\
1\end{array}$ & $\begin{array}{l}1 \\
1\end{array}$ & $\begin{array}{l}2 \\
2\end{array}$ \\
\hline $\begin{array}{r}+12 \\
+10 \\
+8 \\
+6\end{array}$ & $\begin{array}{r}6 \\
6 \\
12 \\
14\end{array}$ & $\begin{array}{r}4 \\
8 \\
9 \\
11\end{array}$ & $\begin{array}{l}10 \\
14 \\
21 \\
25\end{array}$ & $\begin{array}{r}-2 \\
9 \\
12\end{array}$ & $\begin{array}{r}2 \\
6 \\
13 \\
10\end{array}$ & $\begin{array}{r}2 \\
8 \\
22 \\
22\end{array}$ \\
\hline $\begin{array}{r}+4 \\
+2 \\
0 \\
-2\end{array}$ & $\begin{array}{l}17 \\
12 \\
33 \\
21\end{array}$ & $\begin{array}{l}20 \\
15 \\
20 \\
22\end{array}$ & $\begin{array}{l}37 \\
27 \\
53 \\
43\end{array}$ & $\begin{array}{l}35 \\
56 \\
40 \\
39\end{array}$ & $\begin{array}{l}29 \\
36 \\
26 \\
37\end{array}$ & $\begin{array}{l}64 \\
92 \\
66 \\
76\end{array}$ \\
\hline $\begin{array}{r}-4 \\
-6 \\
-8 \\
-10\end{array}$ & $\begin{array}{r}36 \\
27 \\
21 \\
9\end{array}$ & $\begin{array}{l}25 \\
23 \\
16 \\
19\end{array}$ & $\begin{array}{l}61 \\
50 \\
37 \\
28\end{array}$ & $\begin{array}{r}23 \\
20 \\
8 \\
3\end{array}$ & $\begin{array}{l}42 \\
21 \\
13 \\
10\end{array}$ & $\begin{array}{l}65 \\
41 \\
21 \\
13\end{array}$ \\
\hline $\begin{array}{l}-12 \\
-14 \\
-16 \\
-18\end{array}$ & $\begin{array}{r}11 \\
8 \\
3 \\
2\end{array}$ & $\begin{array}{r}16 \\
7 \\
8 \\
9\end{array}$ & $\begin{array}{l}27 \\
15 \\
11 \\
11\end{array}$ & $\begin{array}{l}3 \\
1 \\
1 \\
1\end{array}$ & $\begin{array}{l}1 \\
1 \\
2 \\
2\end{array}$ & $\begin{array}{l}4 \\
2 \\
3 \\
3\end{array}$ \\
\hline $\begin{array}{l}-20 \\
-22 \\
-24 \\
-26\end{array}$ & $\begin{array}{l}\frac{3}{-} \\
-\end{array}$ & $\begin{array}{l}1 \\
3 \\
2 \\
4\end{array}$ & $\begin{array}{l}4 \\
3 \\
2 \\
4 \\
\end{array}$ & $\begin{array}{l}- \\
\overline{-}\end{array}$ & $\frac{1}{1}$ & $\frac{1}{1}$ \\
\hline \multirow[t]{2}{*}{$\begin{array}{l}-28 \\
-30 \\
-34 \\
-36\end{array}$} & $\begin{array}{r}1 \\
1 \\
-\end{array}$ & $\begin{array}{l}2 \\
1 \\
1 \\
2\end{array}$ & $\begin{array}{l}3 \\
2 \\
1 \\
2\end{array}$ & & & \\
\hline & 255 & 255 & 510 & 255 & 255 & 510 \\
\hline
\end{tabular}


differences that are nil are excluded 36 per cent of $\mathrm{A} 1 \mathrm{C} 2,31$ per cent of $\mathrm{C} 1 \mathrm{~A} 2$, and 33 per cent of the combined distributions observations are positive in sign. The corresponding precentages of observations with positive sign for diastolic blood pressure are 54, 43, and 48. A further indication of the observer error effect as between observers $\mathrm{A}$ and $\mathrm{C}$ is the fact that the frequency distributions of the observer differences $\mathrm{A} 1 \mathrm{C} 2$ and $\mathrm{C} 1 \mathrm{~A} 2$ for the two criteria of blood pressure present chi squares with probabilities less than 0.01 (Table III) and thus differ significantly.

TABLE III

The Significance of the Difference between the Frequency Distributions for Systolic and Diastolic Blood Pressure

\begin{tabular}{|c|c|c|c|c|c|c|}
\hline \multicolumn{4}{|c|}{$\begin{array}{l}\text { A1C2 and C1A2 frequency distributions } \\
\text { compared for- }\end{array}$} & $x^{2}$ & $\mathrm{df}$ & $\mathbf{P}$ \\
\hline $\begin{array}{l}\text { Systolic blood pressure } \\
\text { Diastolic blood pressure }\end{array}$ & $\begin{array}{l}\cdots \\
\cdots\end{array}$ & $\begin{array}{l}\cdots \\
\cdots\end{array}$ & $\begin{array}{l}\cdots \\
\cdots\end{array}$ & $\begin{array}{l}37 \cdot 8 \\
39 \cdot 7\end{array}$ & $\begin{array}{r}11 \\
8\end{array}$ & $\begin{array}{l}<0.01 \\
<0.01\end{array}$ \\
\hline
\end{tabular}

The correlation coefficients of the second recordings of systolic and diastolic blood pressure with respect to their observer differences are $0.117 \pm 0.04$ and $0.211 \pm 0.04$ respectively. With increase in blood pressure, there is an approximation of the negative difference means to zero, and in the uppermost part of the blood pressure ranges the averages are positive in sign (Table IV). The

TABLE IV

Observer Difference Related to the Second Readings of the Blood Pressure

\begin{tabular}{|c|c|c|c|c|c|c|c|c|c|c|c|}
\hline & \multicolumn{11}{|c|}{ Systolic blood pressure } \\
\hline & \multicolumn{2}{|c|}{$100 \mathrm{~mm}$. } & \multicolumn{2}{|c|}{$120 \mathrm{~mm}$. } & \multicolumn{2}{|c|}{$140 \mathrm{~mm}$. } & $160 \mathrm{~mm}$. & $180 \mathrm{~mm}$. & $200 \mathrm{~mm}$. & $220 \mathrm{~mm}$. & $240 \mathrm{~mm}$. \\
\hline \multirow[t]{3}{*}{$\begin{array}{l}\text { Number of cases } \\
\text { Observer difference } \\
\text { means. mm. Hg }\end{array}$} & \multicolumn{2}{|c|}{$\begin{array}{c}6 \\
-6.0\end{array}$} & \multicolumn{2}{|c|}{$\begin{array}{c}64 \\
-4 \cdot 5\end{array}$} & \multicolumn{2}{|c|}{$\begin{array}{c}123 \\
-2 \cdot 7\end{array}$} & $\begin{array}{c}126 \\
-3 \cdot 1\end{array}$ & $\begin{array}{c}93 \\
-4 \cdot 4\end{array}$ & $\begin{array}{c}40 \\
-3 \cdot 8\end{array}$ & $\begin{array}{r}33 \\
+1.0\end{array}$ & $\begin{array}{r}25 \\
+1 \cdot 7\end{array}$ \\
\hline & \multicolumn{11}{|c|}{ Diastolic blood pressure } \\
\hline & $\begin{array}{c}\text { Under } \\
72 \mathrm{~mm} \text {. }\end{array}$ & & $\mathrm{mm}$ & 80 & $\mathrm{~nm}$. & $88 \mathrm{~mm}$. & $96 \mathrm{mr}$ & $104 \mathrm{~mm}$. & $112 \mathrm{~mm}$. & $120 \mathrm{~mm}$. & $\begin{array}{l}128 \mathrm{~mm} \text {. } \\
\text { and over }\end{array}$ \\
\hline $\begin{array}{l}\text { Number of cases } \\
\text { Observer differ- } \\
\text { ence means } \\
\text { mm. } \mathbf{H g}\end{array}$ & $\begin{array}{r}24 \\
-1 \cdot 1\end{array}$ & & $\begin{array}{l}78 \\
-2 \cdot 8\end{array}$ & & $\cdot 4$ & $\begin{array}{r}117 \\
-0 \cdot 7\end{array}$ & $\begin{array}{r}94 \\
-0 \cdot(\end{array}$ & $\begin{array}{r}38 \\
+1.0\end{array}$ & $\begin{array}{r}29 \\
+0.9\end{array}$ & $\begin{array}{r}12 \\
+1 \cdot 8\end{array}$ & $\begin{array}{r}7 \\
+2 \cdot 6\end{array}$ \\
\hline
\end{tabular}

regressions of the difference means in relation to the blood pressure ranges are linear for systolic and diastolic blood pressure (the variance ratios are 1.8 and 0.5 respectively). The 0.5 per cent level of significance of the variance ratio is $2 \cdot 09$.

\section{Discussion}

The negative observer difference averages indicate that when the blood pressures of a series of subjects are recorded by one observer reading shortly after another observer there is a fall in average blood pressure. The fall has two components, namely, an observer error and changes due to time sequence between recordings. Furthermore, (1) the observer error is significant for systolic but not for diastolic blood pressure, (2) the means of the observer differences A1C2 and C1A2 and both combined are least for diastolic blood pressure. Thus the criterion of blood pressure that can be recorded by two observers with the greatest accuracy is diastolic blood pressure. In general, the 
decline in blood pressure occurring when a second reading is taken shortly after the first is small. The change on average is $-3.0 \mathrm{~mm}$. for the systolic, and $-0.5 \mathrm{~mm}$. for the diastolic blood pressure.

In the upper part of the blood pressure range, there is an increased chance of the second observer reading higher than the first observer. A second reading immediately after the first and by a different observer is not thought adequate evidence for discussing how much the blood pressure changes with repeated readings. Nevertheless this occurrence may parallel the findings of McWilliam and Kesson (1913) who, in a study of systolic blood pressure with reference to the influence of the arterial wall, observed on occasion people in whom a repetition of blood pressure recording produced an increase in blood pressure. They suggested that this positive response was due to a defective functioning of the normal mechanism that compensates for alteration in peripheral resistance.

\section{SUMMARY}

The observer error in the recording of blood pressure by two observers has been assessed with reference to 510 men and women aged 60 to 89 years.

In this series, the average fall of the blood pressure criteria that occurs when the second observer records the blood pressure shortly after the first observer is very small, $3.0 \mathrm{~mm}$. for the systolic and $0.5 \mathrm{~mm}$. for the diastolic blood pressure. The observer error is significant $(2.6 \mathrm{~mm} . \pm 0.81)$ for the systolic but is not significant $(0.8 \mathrm{~mm} . \pm 0.45)$ for the diastolic blood pressure. In addition, the frequency distributions of the recordings of the two observers differ significantly for systolic and diastolic blood pressure.

We wish to thank Dr. P. L. McKinlay for helpful guidance and the Secretary of State for Scotland for a personal grant made on the advice of the Advisory Committee on Medical Research.

\section{REFERENCES}

Anderson, W. F., and Cowan, N. R. (1955). Lancet, 2, 239.

McWilliam, J. S., and Kesson, J. E. (1913). Heart, 4, 279.

Standardization of Methods of Measuring the Arterial Blood Pressure (1939). Brit. Heart J., $1,261$. 